\title{
TRANSFORMASI PRANATA PATRONASE MASYARAKAT NELAYAN: DARI EKONOMI MORALITAS MENUJU EKONOMI PASAR
}

\author{
Mirajiani $^{1 凶}$, Ekawati S.Wahyuni ${ }^{2}$, Arif Satria ${ }^{3}$, Saharuddin ${ }^{4}$, Tridoyo Kusumastanto ${ }^{5}$ \\ ${ }^{1}$ Mahasiswa Program Doktor Sekolah Pascasarjana Program Studi Sosiologi Pedesaan IPB. Bekerja di Fakultas \\ Pertanian Universitas Sultan Ageng Tirtayasa, Serang, Banten \\ ${ }^{2}$ Dosen Departemen Sains Komunikasi dan Pengembangan Masyarakat. Fakultas Ekologi Manusia IPB. \\ Ketua Komisi Pembimbing \\ ${ }^{3}$ Dosen Departemen Sains Komunikasi dan Pengembangan Masyarakat. Fakultas Ekologi Manusia IPB. \\ Anggota Komisi Pembimbing \\ ${ }^{4}$ Dosen Departemen Sains Komunikasi dan Pengembangan Masyarakat. Fakultas Ekologi Manusia IPB. \\ Anggota Komisi Pembimbing \\ ${ }^{5}$ Guru Besar Kebijakan Ekonomi Kelautan, Fakultas Ekonomi dan Manajemen IPB. \\ Anggota Komisi Pembimbing
}

Permalink/DOI: http://dx.doi.org/10.15294/komunitas.v6i1.2950

\begin{tabular}{l} 
Article History \\
\hline Received : Desember 2013 \\
Accepted : Januari 2014 \\
Published : Maret 2014 \\
\hline
\end{tabular}

\section{Keywords}

Transformation; Fish-

ermen; Patronage;

Economic Security

\begin{abstract}
Abstrak
Masyarakat nelayan mengalami transformasi sosial ekonomi akibat penetrasi pembangunan dan pasar. Transformasi sosial ekonomi yang terjadi membawa perubahan signifikan pranata ekonomi nelayan, karena nelayan harus mengkonstruksikan pranata ekonomi baru yang dianggap dapat mempertahankan penghidupan nelayan pada kondisi survival dan sesuai dengan perubahan yang terjadi. Penelitian ini mendalami bagaimana transformasi pranata patronase yang terjadi dan keterkaitannya dengan keterjaminan ekonomi pada masyarakat nelayan di Pesisir Ujung Kulon. Metode penelitian menggunakan pendekatan kualitatif dengan tipe penelitian studi kasus. Hasil penelitian menunjukkan masyarakat nelayan di Pesisir Ujung Kulon mengalami transformasi pranata ekonomi dari patronase berbasis moralitas menjadi berbasis norma ekonomi pasar. Di era ekonomi pasar, patronase merupakan suatu alternatif pranata ekonomi nelayan yang dibangun untuk tetap bertahan dengan situasi krisis dan ketidakpastian ekonomi serta mata pencaharian yang bersifat fluktuatif. Ditinjau dari keterjaminan ekonomi, pranata patronase moralitas di masa lalu lebih memberikan jaminan ekonomi nelayan pada situasi krisis daripada pranata patronase berbasis norma ekonomi pasar. Pada situasi di mana pranata patronase tidak bisa sepenuhnya berfungsi sebagai pranata jaminan ekonomi nelayan, maka untuk tetap bertahan pada situasi ekonomi yang kurang terjamin nelayan mengandalkan relasi ekonomi alternatif yang disediakan pasar di luar patronase.
\end{abstract}

\section{TRANSFORMATION OF PATRONAGE INSTITUTION IN FISHING COMMUNITIES: FROM ECONOMIC MORALITY TO MARKET ECONOMY}

\begin{abstract}
Fishing communities experiencing socio-economic transformation as a result of development and market penetration. Socio-economic transformation is followed by significant change in economic institutions, as fishermen have to construct a new economic institutions which are supposed to maintain the livelihood in survival conditions and in accordance with the changes. This research was to explore how economic institution transformation happens and its effect on economic security in coastal fishing communities in Ujung Kulon. The method uses a qualitative approach and the type of research uses a case study research. Results of the research showed coastal fishing communities in Ujung Kulon transformed economic institutions of patronage based morality becomes the norm based market economy. In the era of market economy, patronage remains an alternative economic institutions built to survive the crisis and uncertainty and livelihood fluctuated. The fact is related to economic security, institutional patronage morality in the past to provide security over the fishing economy in crisis situations rather than norm -based patronage institutions of the market economy. In situations where the institution of patronage can not fully function as economic security institutions of fishermen, then to survive on less secure economic situation of fishermen rely on alternative economic relations are provided markets outside patronage.
\end{abstract}

(c) 2014 Universitas Negeri Semarang

\footnotetext{
*Naskah merupakan bagian dari Disertasi

$\triangle$ Corresponding author :

Address: Jalan Jend. Ahmad Yani, Banten 42434, Indonesia

E-mail: mirajiani@yahoo.com
} 


\section{PENDAHULUAN}

Masalah sentral yang dihadapi oleh para nelayan adalah sifat mata pencaharian yang lekat dengan resiko krisis dan ketidakpastian (crisis risk and uncertainty) yang disebabkan beberapa hal, antara lain (1) dalam kegiatan mencari nafkah nelayan sangat tergantung dengan cuaca/iklim yang berubah-ubah, (2) nelayan sangat tergantung pada sumber daya laut yang saat ini terpapar pada perubahan global yang disebabkan oleh climate change atau perubahan yang disebabkan oleh ulah manusia (human made), (3) penguasaan teknologi perikanan yang masih rendah, (4) nelayan menghadapi masalah dalam hal penyediaan sarana dan prasarana, (5) aktivitas mencari nafkah nelayan sangat tergantung pada ketersediaan modal finansial. Dengan segala resiko krisis dan ketidakpastian tersebut seringkali nelayan dikategorikan sebagai kelompok masyarakat miskin dari kelompok yang paling miskin (poor of the poorest).

Fakta lainnya adalah masyarakat nelayan saat ini mengalami perubahan sosial akibat penetrasi pembangunan dan pasar. Ideologi kapitalisme dan modernisme yang dibawakan pasar dan program pembangunan oleh negara mempengaruhi aspek struktural dan hubungan sosial dalam pranata ekonomi masyarakat. Adanya perubahan sosial dan semua permasalahan yang dihadapi dalam sistem penghidupan nelayan mengharuskan nelayan mengkonstruksikan mekanisme penjaminan penghidupan melalui transformasi pranata ekonomi yang dianggap dapat mempertahankan penghidupan nelayan pada kondisi survival.

Penelitian ini berawal dari dugaan bahwa keberadaan pranata ekonomi nelayan mampu menyelamatkan masyarakat nelayan dari beragam bentuk resiko krisis dan ketidakpastian. Sistem ekonomi nelayan dengan segala permasalahannya nyatanya tetap memiliki daya survivalitas hingga saat ini. Daya survivalitas tersebut pada dasarnya berakar dari aspek struktural termasuk pranata (kelembagaan) ekonomi nelayan, oleh karena bekerjanya pranata ekonomi akan mengkait dengan tindakan pemenuhan penghidupan nelayan, khusus- nya tindakan ekonomi nelayan dalam rangka survivalitas dari krisis.

Pranata ekonomi akan terkait dengan struktur ekonomi dan struktur sosial yang terbentuk. Pengertian pranata dalam konteks ini memaknai dari teori Weber (1958) tentang struktur sosial dan institusi sosial. Menurut Weber, struktur sosial akan tampil berupa kemantapan hubungan antar individu dalam konfigurasi hubungan sosial atau konfigurasi jejaring sosial yang kompleks, saling mempertukarkan sesuatu yang dianggap bernilai dan memiliki ekspektasi bersama (shared expectation) secara mantap dalam sistem sosial. Kemudian, pranata sosial akan berkembang dari kebiasaan bersama hingga kelakuan normatif yang dikukuhkan dengan aturan-aturan termasuk sistem reward dan sanction yang dipelihara oleh sistem norma dan hukum dalam masyarakat. Artinya dalam skala mikro setiap perilaku masyarakat akan tertuntun oleh pranata yang menjadi aturan main dalam sistem sosial masyarakat. Konsep pranata ekonomi yang digunakan dalam penelitian ini merupakan bagian dari pranata sosial yang berfungsi mengatur tata hubungan sosial dan ekonomi (rules of the game) antara satu individu dengan individu lainnya yang memiliki peran sosial yang berbeda-beda dalam konfigurasi sosial dan jejaring sosial tertentu.

Pranata ekonomi yang dianggap penting dalam sistem penghidupan nelayan adalah pranata patronase. Patronase merupakan hubungan ekonomi vertikal dengan ikatan tertentu yang terjalin antara dua pihak yang berbeda dalam penguasaan sumber daya. Dari hubungan tersebut ada arus pertukaran timbal balik namun tidak menjamin satu pihak mendapatkan imbalan yang setimpal dengan pihak lain. Adakalanya yang terjadi justru eksploitasi satu pihak yang menguasai sumber daya lebih banyak terhadap pihak yang memiliki nihil atau sedikit sumber daya.

Secara teoritis, ada beberapa pendapat yang dapat disandingkan dalam hal pranata ekonomi patronase. Scott (1972) mengemukakan patronase merupakan hubungan ekonomi vertikal yang memiliki aturan 
main tersendiri, seperti yang dikemukakan sebagai berikut:

The patron client - an exchange relationship between roles- may be defined as a special case of dyadic (two person) ties involving a largely instrumental friendship in which an individual of higher socioeconomic status (patron) uses his own influence and resources to provide protection or benefits, or both, for a person of lower status (client) who, for his part, reciprocates by offering general support and assistance, including personal services to the patron.

Patron klien disebutnya sebagai hubungan pertukaran antara peran di mana satu pihak memiliki status sosial ekonomi lebih tinggi (patron) menggunakan pengaruh dan sumber daya sendiri untuk memberikan perlindungan atau manfaat, atau keduanya, untuk pihak yang memiliki status lebih rendah (klien) yang membalasnya dengan menawarkan dukungan umum dan bantuan, termasuk jasa pribadi kepada patron.

Pendapat Scott di atas mengandung makna moralitas yang terkandung dalam ikatan ekonomi vertikal, di mana kedua belah pihak yang terlibat dalam satu ikatan saling beresiprositas dan bertukar dalam hal manfaat hubungan keduanya. Definisi inilah semakin mengukuhkan posisi Scott sebagai salah seorang eksponen dari aliran ekonomi moral. Dalam karyanya yang lain Scott juga menjelaskan bahwa pranata ekonomi ekonomi patronase merupakan sistem ekonomi yang terbangun atas solidaritas ekonomi kolektif yang informal untuk menjaga kepentingan subsistensi pihak ekonomi lemah. Dengan anggapan seperti ini sepertinya Scott mendudukkan pranata ekonomi patronase berfungsi sebagai pranata jaminan sosial masyarakat yang disebutnya sebagai asuransi sosial. Digambarkan bahwa dalam pola relasi ekonomi pertukaran dimainkan nilai-nilai ekonomi moral yang melandasi resiprositas dan etika ekonomi yang dianggap sangat ampuh untuk memberikan jaminan keamanan sistem penghidupan masyarakat pada pada tingkat subsisten. Pendapat senada juga dikemukakan Khan (2001), bahwa dalam sistem produksi agraria yang cenderung subsisten di Asia Selatan dan Asia Tenggara pada umumnya, maka pranata patronase merupakan relasi struktural moralitas yang menentukan survivalitas sosial terutama dalam sistem produksi dan distribusi. Lyon (2002) memperkuat kedua pendapat di atas bahwa patronase berbasis moralitas dalam pertukaran sosial memang lazim terdapat dalam masyarakat yang baru berkembang dan digambarkan sebagai hubungan pribadi yang berwujud jaringan sosial antara dua pihak atau lebih yang melakukan relasi yang bersifat sukarela dan timbal balik yang didasarkan pada hubungan kekeluargaan dan kedekatan secara sosial.

Sebaliknya dari aliran ekonomi rasional, pranata ekonomi patronase memiliki makna yang berbeda dari pengertian patronase yang telah dikemukakan tokoh-tokoh aliran ekonomi moralitas. Popkin (1986) membenarkan bahwa sistem pranata ekonomi patronase lekat dengan masyarakat Asia tenggara, namun Popkin tidak setuju dengan pendapat yang mengatakan bahwa etika ekonomi yang bermain dalam pranata ekonomi patronase dilandasi ekonomi moral. Menurutnya, petani Asia Tenggara sangat rasional, sehingga etika-etika ekonomi, pola relasi dan rasionalitas yang mendasarinya sudah mencerminkan bahwa petani sudah benar-benar rasional. Popkin sa-

Ingat percaya pada kekuatan pasar. Pendapat Scott tentang kemurahan hati patron (basis ekonomi moral Scott) menjamin subsistensi klien dengan tujuan melanggengkan hubungan ekonomi dan meniadakan pengaruh pasar ditentang secara total oleh Popkin. Menurutnya tidak mendasar sama sekali apabila patron telah menjamin subsistensi, maka klien akan terus menerus memberi patron legitimasi karena petani-petani akan berjuang merebut otonominya jika pasar menyediakan alternatifalternatif yang baik bagi dirinya. Popkin menambahkan tiga kritikan utama terhadap basis ekonomi moral dalam ikatan ekonomi patronase yang dikemukakan Scott, antara lain (1) bahwa tidak ada hubungan 
yang jelas antara ancaman atau alasan subsistensi dengan respon ekonomi kolektif yang terjelma dalam patronase berbasis moral, (2) Ada perbedaan yang nyata antara rasionalitas individual dengan rasionalitas kolektif, sehingga tidak benar keduanya dapat disatukan, (3) Argumentasi bahwa patronase dapat menjamin subsistensi dengan sempurna tidak dapat dibuktikan.

Penggambaran para pencetus teoritis konsep patronase yang telah dikemukakan di atas, umumnya berdasarkan pada studi terhadap masyarakat petani, bukan masyarakat nelayan. Namun, kenyataannya prinsip tentang pranata ekonomi patronase petani sebenarnya tidak terlalu jauh berbeda dengan patronase yang ada dalam masyarakat nelayan. Walaupun ada perbedaan, hal ini lebih didasarkan pada perbedaan khusus yang mendasari keduanya. Sumber daya laut yang menjadi sumber daya utama kegiatan mencari nafkah nelayan bersifat open access, sementara sumber daya tanah yang menjadi sumber daya terpenting petani dalam kondisi sebaliknya yaitu jumlahnya terbatas. Menurut Basurto (2013), strategi kelembagaan patronase merupakan hal umum yang dipilih oleh masyarakat yang terlibat pada mata pencaharian perikanan dan di era globalisasi dan komersialisasi sekalipun, bentuk kerjasama kolektif ini akan tetap dipertahankan. Eksistensi pranata patronase pada masyarakat nelayan juga dikemukakan oleh Verelst (2013) yang mengemukakan bahwa masih eksisnya pola relasi patronase pada nelayan kecil (a small scale fishery) mencerminkan bahwa ekonomi politik perikanan yang cenderung inequality masih bertahan.

Dalam penelitian ini, fakta yang terjadi adalah bahwa kedua bentuk patronase, baik yang dikemukakan oleh aliran ekonomi moralis dan aliran ekonomi rasional samasama nyata dalam masyarakat yang diteliti. Namun keberadaan kedua bentuk patronase tersebut diletakkan dalam konteks historikal dan perubahan masyarakat pada saat pra ekonomi pasar dan ketika sepenuhnya mengenal ekonomi pasar. Penelitian ini akan mendalami bagaimana transformasi pranata ekonomi yang terjadi dan keterkai- tannya dengan keterjaminan ekonomi pada masyarakat nelayan di Pesisir Ujung Kulon.

\section{METODE PENELITIAN}

Penelitian berlokasi di Desa Pesisir Ujung Kulon, yaitu Desa Sumberjaya, Kecamatan Sumur, Kabupaten Pandeglang, Provinsi Banten. Penelitian ini menggunakan pendekatan kualitatif dengan tipe penelitian studi kasus. Penelitian studi kasus diterapkan pada suatu komunitas, karena sesuai dengan keterwakilannya dengan karakteristik permasalahan dan tujuan penelitian. Pemilihan strategi penelitian studi kasus didasarkan pada (1) kesesuaian dengan pertanyaan penelitian yang bersifat eksploratif, (2) peluang peneliti sangat kecil untuk mengontrol peristiwa/gejala sosial yang hendak diteliti dan (3) pumpunan penelitian adalah peristiwa/gejala sosial kontemporer (masa kini) dalam kehidupan.

Pilihan pendekatan kualitatif sesuai dengan tujuan penelitian yaitu pemahaman secara mendalam tentang transformasi pranata patronase yang terjadi dan keterkaitannya dengan keterjaminan ekonomi pada masyarakat nelayan di Pesisir Ujung Kulon. Artinya peneliti berangkat dari asumsi ontologis bahwa realitas yang ada bersifat subjektif dan sebagaimana halnya yang dipahami dan dimaknai oleh peneliti. Metode pengumpulan data yang dilakukan berupa pengamatan (observasi), wawancara mendalam (in depth interview) dan studi literatur. Data penelitian terdiri dari data primer dan data sekunder. Data primer akan dikumpulkan melalui wawancara mendalam pada informan-informan yang berasal dari masyarakat dan diskusi-diskusi informal yang berlangsung dalam berbagai kesempatan yang ada secara spontan. Data sekunder didapat melalui studi literatur dilakukan pada sumber-sumber teori dan kasus-kasus penelitian lain yang terkait dengan penelitian ini. Pengamatan akan dilakukan secara cermat untuk mengamati pranata patronase masyarakat nelayan sebagai sebuah sistem yang memiliki aspek-aspek tertentu, hubungan-hubungan yang khas dan mekanisme yang berlangsung tersendiri. 
HASIL DAN PEMBAHASAN

\section{Pranata Patronase Berbasis Moralitas} Di Era Pra Ekonomi Pasar

Secara teoritis pranata ekonomi akan terkait dengan struktur ekonomi yang terbentuk artinya pranata ekonomi masyarakat nelayan Ujung Kulon di masa lalu yang terbentuk tidak bisa lepas dari struktur sosial dan situasi ekonomi pada masa itu. Di masa lalu struktur ekonomi masyarakat Ujung Kulon digambarkan relatif terisolasi karena wilayah ini belum memiliki akses keluar masuk wilayah dengan lancar. Ketika wilayah ini masih menjadi bagian dari Provinsi Jawa Barat, di era awal munculnya pemukiman masyarakat sampai tahun 1980-an, desa-desa di pesisir Ujung Kulon merupakan desa-desa yang secara ekonomi terisolasi dari dunia luar. Hal ini disebabkan prasarana jalan dan sarana transportasi yang kurang memadai.

Sebenarnya kampung-kampung di Pesisir Ujung Kulon sudah terbentuk pada tahun 1930-an, penduduknya merupakan penduduk asli setempat. Pada masa itu juga mulai ada migrasi nelayan dari Labuan, Carita dan Binuangeun. Adanya migrasi ini pula yang mendorong perkembangan perekonomian setempat. Pertambahan penduduk nelayan baik dari migrasi maupun pertambahan penduduk lokal mendorong pencetakkan sawah dan kebun kelapa di sepanjang pesisir Ujung Kulon. Mata pencaharian utama penduduk pada waktu itu justru sebagai petani sawah dan mengambil hasil hutan seperti madu, aren, jengkol, rotan dan lain-lain, oleh karena hasil laut tidak memiliki saluran pemasaran sehingga tidak terlalu bernilai ekonomis. Bertanam padi di sawah dianggap lebih memenuhi keterjaminan kebutuhan pangan (beras) yang dianggap lebih safety dibandingkan menjadi nelayan di mana hasil tangkapan ikan tidak bisa dipasarkan kecuali untuk memenuhi kebutuhan lokal. Penduduk setempat umumnya memiliki keterampilan melaut dan memiliki alat melaut tradisional, sehingga walaupun mata pencaharian mereka sebagai petani, mereka sesekali melakukan aktivitas melaut untuk mencukupi kebutuhan lauk pauk rumah tangga.
Pada saat itu kebutuhan pangan dan sandang penduduk lokal dipenuhi dengan cara barter. Jikalau hasil tangkapan melebihi kebutuhan, mereka melakukan barter dengan barang kebutuhan lain seperti beras, sayuran, kelapa dan lain-lain. Satu-satunya kontak dengan dunia luar ketika sesekali ada pedagang dari luar wilayah pesisir memasuki wilayah ini dengan menggunakan alat transportasi kuda. Mereka membawa kebutuhan yang tidak dapat dicukupi dengan sumber daya lokal seperti garam, gula, teh, tekstil dan lain-lain. Barang-barang kebutuhan ini ditukar dengan hasil sawah (beras) dan hasil hutan seperti (madu, gula aren, jengkol dan rotan).

Gambaran struktur ekonomi masyarakat pada masa ini tentu saja sangat sederhana dan tradisional. Setiap aktivitas perekonomian hanya ditujukan untuk memenuhi kebutuhan subsisten keluarga. Dalam satu keluarga secara ekonomi merupakan unit produksi dan konsumsi. Mereka juga tidak menghadapi kendala dalam hal penyediaan sumber daya, oleh karena dibandingkan dengan sumber daya yang tersedia baik sumber daya hutan, tanah dan laut, jumlah penduduk yang memanfaatkan sumber daya tersebut relatif masih sedikit. Masyarakat memiliki pilihan-pilihan dalam aktivitas ekonomi untuk mencukupi kebutuhan. Ketika mereka membutuhkan bahan pangan pokok berupa beras, dapat dipenuhi dari hasil pencetakan sawah. Ketika mereka membutuhkan lauk pauk untuk makan, mereka bisa memancing atau menjaring ikan di laut, ketika membutuhkan sandang atau pakaian, atau kebutuhan-kebutuhan lainnya yang tidak dapat dicukupi dengan sumber daya lokal, mereka akan masuk ke hutan mengambil hasil hutan yang pada saat itu memiliki nilai ekonomis tinggi bagi orang di luar wilayah.

Di era tahun 1945-an, dibangun bandar (pelabuhan tradisional) di Kampung Sumur (Desa Sumberjaya pada masa kini). Keberadaan bandar memberi arti penting bagi perkembangan perekonomian dan titik awal bagi masyarakat pesisir Ujung Kulon mengenal pasar yang lebih luas. Beberapa perubahan dan perkembangan yang pen- 
ting dari sisi ekonomi antara lain (1) Bandar membuka akses keluar masuk wilayah menjadi lebih lancar, (2) Penduduk setempat mulai mengenal sistem ekonomi uang dari transaksi ekonomi yang dilakukan, (3) Peningkatan nilai ekonomis dari produk yang dihasilkan dari sumber daya lokal.

Adanya bandar sebagai pelabuhan tradisional membuka peluang kapal-kapal dagang tradisional singgah di bandar tersebut dan memungkinkan mengangkut produk sumber daya lokal dalam jumlah besar ke luar wilayah seperti Labuan, Serang, Carita dan Binuangen. Keberadaan bandar juga mengundang pemodal-pemodal luar yang masuk ke wilayah ini dan mulai membangun usahanya termasuk di bidang perikanan. Pada masa itu pula, mulai digunakan alat transportasi laut tembon (perahu besar) yang tidak hanya mengangkut produk sumber daya, namun juga mengangkut manusia yang masuk dan keluar wilayah. Dengan berjalannya waktu, pedagang-pedagang atau pemodal-pemodal lainnya dari luar wilayah seperti Labuan, Carita dan Binuangeun masuk wilayah ini dan tentu saja juga membawa modal/sumber daya yang lebih besar, orang-orang inilah yang kemudian secara ekonomi memacu perkembangan wilayah dan juga pada akhirnya menjadi patron dari sebuah pranata ekonomi patronase yang mulai terbentuk

Dengan adanya pedagang ikan yang keluar masuk wilayah, ikan sebagai salah satu produk andalan mengalami peningkatan dari segi ekonomis dengan permintaan yang meningkat dari waktu ke waktu. Peningkatan permintaan terhadap ikan sebagai hasil laut, justru mendorong aktivitas mencari ikan di laut menjadi aktivitas utama, sehingga banyak penduduk yang memiliki mata pencaharian utama sebagai nelayan. Mata pencaharian ini semakin berkembang dengan masuknya pengusaha "pengasinan" dan "pindang ikan" ke wilayah ini. Produk ikan tidak dapat diperjualbelikan dalam kondisi segar, karena pada masa itu belum ada box pendingin maupun es batu/balok, sehingga ikan segar harus diolah terlebih dahulu menjadi ikan asin/ikan kering atau ikan pindang baru kemudian dipasarkan. Hal ini pula yang mendorong semakin berkembangnya usaha-usaha pengasinan dan membuat pindang di wilayah ini. Pengusaha pengasinan/pindang ikan yang juga merupakan pedagang ikan antar wilayah membutuhkan pasokan ikan secara tetap dan terjaga untuk menjamin usahanya terus berjalan, sehingga pengusaha ini mengambil nelayan-nelayan tertentu untuk menjadi anak buahnya secara tetap dan diberikan peralatan melaut seperti jukung, congkreng, jaring dan pancing. Setiap hasil tangkapan melaut harus dipasok kepada pengusaha yang bersangkutan sebagai bahan baku ikan asing/kering dan ikan pindang.

Di era inilah pranata ekonomi patronase berbasis moralitas dalam sistem ekonomi nelayan setempat yang bertahan hingga di era tahun 1980-an. Pada saat itu nelayan mengandalkan jaminan dan perlindungan patron (para pemodal dan pengusaha dari luar wilayah) untuk memenuhi kebutuhan subsistensi mereka, terutama pada saat krisis. Sebagai gantinya para nelayan menjadi anak buahnya yang setia yang siap melakukan pekerjaan apa saja yang diberikan kepadanya.

Menurut H Id (72 th):

"Dahulu, zaman perahu tembon, nelayan banyak yang jadi anak buah pengasin, tidak jual ikan sendiri. Kalaupun ada yang jual ya kepada penduduk sini, yang beli sedikit harganya juga ga seberapa, kadang dibarter sama beras. Jika menjadi anak buah pengasin, disuruh cari ikan ke laut, jukung dikasih, dikasih makan, ikannya untuk diasin, anak istri di rumah juga dijamin hidupnya oleh pengasini. Lagipula kebutuhan zaman dulu tidak banyak, cukup makan, pakaian, kalau sakit ada yang bawa ke orang pintar. Tidak semua nelayan punya sawah, kalau tidak pengasin ngasih jaminan, ..mereka balik ke hutan lagi cari hasil hutan, di barter sama beras.

Etika subsistensi memberi dasar pada berkembangnya ekonomi yang memiliki dimensi normatif atau moral. Hal ini mendorong terbentuknya struktur resiprositas dan tindakan ekonomi atas resiko krisis subsis- 
tensi yang didasarkan pada basis normatif dan moral.

\begin{abstract}
Menurut H. Af (75 th):
Dulu, tidak seperti sekarang jaman orang mau kaya sendiri, mementingkan diri sendiri, mengumpulkan duit terus yang banyak. Dahulu jaman kita juragannya tanggung jawab, baik, tidak perhitungan, makanya anak buah juga tidak menghitung. Prinsipnya tolong menolong, saling membutuhkan, makanya tanya sama orang-orang dulu, tidak ada istilah anak buah juragan dibajak sama juragan lain seperti sekarang. Sekali jadi anak buah juragan tertentu, akan terus jadi anak buah, sampai tua.
\end{abstract}

Dari keterangan di atas tampak jelas bahwa orientasi aktivitas ekonomi dalam hubungan patronase adalah pemenuhan kebutuhan subsisten klien. Dan setiap pengambilan keputusan ekonomi ditujukan untuk menciptakan harmoni walaupun kedua belah pihak memiliki orientasi kepentingan ekonomi yang berbeda (patron ingin keuntungan dan loyalitas klien dan klien ingin dicukupi semua kebutuhannya). Klien cenderung loyal terhadap patronnya karena patron sudah memberikan jaminan yang pasti atas kebutuhan subsistensinya.

Menurut Bapak Ad (69 th):

Kalau dahulu, masa-masa usaha pengasinan dan pemindangan ikan, nelayan yang jadi anak buah tidak pernah nendo (berhutang). Istilah tendoan(menunggak pembayaran) juga tidak ada. Itu sekarangsekarang saja munculnya. Dulu kalau tidak dapat ikan ya sudah, tidak dihitung hutang sama juragan seperti sekarang ini. Semua kerugian ditanggung juragan. Kalau hasil ikan banyak yang untung juga juragan, yang penting nelayan bisa makan. Kondisinya bisa begitu karena nelayan dulu teu hoyong nanaon (tidak menginginkan) selain cukup makan, kalau sekarang nelayan banyak maunya, mau motor, mau hape, mau rumah bagus, mau makan enak, ya..pasti tidak mau seperti dulu lagi, walau pusing kalau tendoan (hutang) banyak ke juragan, yang penting musim ikan masih ada harapan terima uang banyak, bisa beli-beli.
Pranata ekonomi patronase pada masa ini dapat dikatakan sebagai pranata ekonomi patronase tradisional dengan ciri tertentu yang hampir sama seperti yang dikemukakan Scott (1972) ditambah ciri lain yang bersifat lokalitas, antara lain (1) patron memberikan jaminan penghidupan nelayan sebagai klien di level subsisten, (2) patron memberikan jaminan pada penghidupan nelayan klien pada situasi krisis (subsistence crisis incurance), (3) ) adanya perlindungan dari patron dan pengaruh atas kekuasaan yang dimiliki patron, (4) klien memberikan kesetiaan dan loyalitas kepada patron termasuk mencurahkan tenaganya untuk kepentingan patron, (5) resiko ditanggung oleh patron atau resiko didistribusikan tanpa perhitungan ekonomi dan klien cenderung menghindari resiko dalam usahanya, (6) dasar pengambilan keputusan ekonomi adalah menjaga harmoni atas hubunganhubungan ekonomi yang telah terbina, (7) pertukaran yang terjadi meliputi hal material dan immaterial, (8) persaingan dianggap faktor yang mengganggu keselarasan hubungan ekonomi, (9) kelanggengan hubungan ditentukan terpeliharanya dasar moralitas, (10) peranan modal tidak terlalu vital, yang paling dijaga keharmonisan hubungan, (11) posisi klien tidak memiliki pilihan ekonomi, (12) eksploitasi tertawarkan dengan prinsip moralitas atau eksploitasi seringkali tidak disadari, (13) kedua belah pihak memelihara hubungan patronase sebagai asuransi sosial pada saat krisis.

\section{Pranata Patronase Berbasis Ekonomi Pasar di Era Masa kini}

Tonggak sejarah penting yang menandai dimulainya era ekonomi pasar berlangsung pada tahun 1980-an, dengan dibangun Jalan yang lebar dan dapat dilalui oleh kendaraan roda empat, yang menghubungkan Kecamatan Cibaliung dengan desa-desa pesisir di Kawasan Ujung Kulon. Walaupun pada saat itu kondisi jalan belum diaspal, namun pada saat inilah masyarakat nelayan setempat mulai benar-benar bersentuhan dengan pranata ekonomi pasar secara terbuka. Posisi penting Bandar Sumur semakin berkurang digantikan mobil-mobil pick up 
(bak terbuka) yang mengangkut hasil hutan, kopra dan ikan asin/kering. Pada masa ini pula mulai masuk pemodal-pemodal besar yang bermigrasi dari Cirebon/Indramayu serta Lampung (Orang Jawa dan Bugis yang sebelumnya bermigrasi keLampung). Pada tahun 1985 an di wilayah ini digalakkan kegiatan pariwisata, sehingga bertambah banyaklah orang yang keluar masuk wilayah ini. Adanya akses jalan, migrasi masuk pemodal baru dan kegiatan pariwisata di wilayah ini membawa implikasi ekonomi yang penting kepada penduduk setempat yaitu nelayan memiliki alternatif lain untuk memasarkan hasil tangkapannya. Nelayan dapat menjual ikan tangkapannya kepada para wisatawan maupun pengusaha/pemodal baru yang menetap di wilayah tersebut. Kegiatan pariwisata menyerap tenaga kerja yang berasal dari rumah tangga nelayan, sehingga menciptakan alternatif sumber modal tambahan sehingga nelayan tidak terlalu tergantung dengan sumber permodalan dari patron.

Dengan situasi ini ikatan patron klien yang tadinya merupakan institusi jaminan ekonomi nelayan pada tingkat subsisten menjadi melemah. Dalam hal ini klien tidak terus menerus memberikan legitimasi pada posisi patron, oleh karena pasar yang baru terbuka menyediakan alternatif-alternatif yang lain bagi nelayan untuk memasuki pasar, sehingga dalam hal ini pasar dapat mengurangi bargaining power patron. Kenyataannya para pengusaha yang tadinya juga berstatus sebagai patron tidak bisa bertahan dengan perubahan-perubahan yang ada sehingga kemudian usaha mereka menjadi bangkrut. Secara otomatis kedudukan mereka digantikan oleh pengusaha/ pemodal baru yang bermigrasi sekitar tahun 1980-1985an.

Sejalan dengan adanya perubahan sosial, dalam masyarakat nelayan terjadi juga perubahan teknologi. Hal ini terkait dengan modernisasi perikanan yang juga membawakan teknologi baru, seperti penggunaan kapal motor, diperkenalkannya teknologi penangkapan ikan dengan menggunakan bagan, serta sistem permodalan dengan metode dan cara yang baru.
Transformasi sosial ekonomi yang terjadi membawa perubahan signifikan dalam hal pranata ekonomi patronase. Di era inilah pranata ekonomi patronase memiliki bentuk yang sama sekali berbeda dengan patronase di era sebelumnya. Dari penjelasan di atas dapat diidentifikasi penyebab dari perubahan pranata ekonomi patronase tersebut, antara lain:

Situasi ekonomi yang berubah, antara lain :

1. Komersialisasi produk perikanan (peningkatan nilai ekonomis hampir semua produk perikanan

2. Akses terhadap pasar menjadi lebih mudah dan terbuka karena dibangunnya prasarana jalan dan penambahan sarana transportasi

3. Adanya migrasi keluar dan migrasi masuk. Migrasi keluar mendorong terakumulasinya modal dari luar ke dalam desa karena penduduk yang bermigrasi atau bekerja di luar membawa penghasilannya kembali ke desa. Migrasi masuk kebanyakan adalah para pemodal di sektor perikanan yang membuka peluang investasi modal dari luar

4. Bertambahnya pemodal-pemodal baru yang juga berperan sebagai patron-patron yang baru (notabene bukan orang asli) justru mendorong bargaining power klien lebih meningkat.

5. Mulai ada pasokan dana/modal untuk usaha perikanan dari sektor lain (permodalan lintas sektor) terutama dari sektor pariwisata. Dengan adanya fenomena strategi nafkah berdasarkan alokasi sumber daya manusia (straddling strategy) memungkinkan semua anggota rumah tangga dengan usia produktif terlibat dalam kegiatan mencari nafkah dengan sektor pekerjaan yang berbeda-beda. Anggota rumah tangga dapat menjadi alternatif sumber modal tambahan yang mengurangi ketergantungan terhadap sumber permodalan dari patron.

Modernisasi Perikanan yang membawa perubahan terhadap teknologi penangkapan ikan

1. Introdusi sistem penangkapan ikan 
dengan menggunakan teknologi bagan seiring dengan peningkatan nilai ekonomis komoditas ikan-ikan tertentu

2. Dipergunakannya kapal-kapal motor yang memiliki kapasitas yang lebih besar

Pada era ekonomi pasar, nelayan hampir tidak memiliki institusi patronase berbasis moralitas yang sepenuhnya dapat dijadikan sebagai institusi penjamin ekonomi dalam situasi krisis seperti di masa lalu. Segala aktivitas ekonomi, pertukaran dan transaksi ekonomi serta dasar pengambilan keputusan seluruh pelaku-pelaku ekonomi sepenuhnya didasarkan pada norma-norma pasar. Ditambah lagi situasi sosial yang juga turut berubah, menjadikan semakin sulit bagi pelaku-pelaku ekonomi dalam masyarakat nelayan untuk mempertahankan dasar moralitas dalam tindakan ekonomi mereka. Pada masa kini, di era ekonomi pasar, patronase tetap merupakan merupakan suatu alternatif pranata ekonomi yang dibangun untuk untuk menjaga keberlangsungan kegiatan ekonomi dan tetap bertahan pada situasi krisis dan ketidakpastian serta mata pencaharian yang bersifat fluktuatif, namun pranata patronase mengalami perubahan (transformasi) seiring dengan adanya transformasi sosial ekonomi masyarakat nelayan yang terjadi.

\section{Bentuk-bentuk Patronase Berbasis Eko- nomi Pasar}

Mayoritas nelayan tangkap di Pesisir Ujung Kulon menggunakan alat tangkap bagan dan jaring. Alat tangkap bagan (perahu, tancap dan apung) digunakan nelayan bagan untuk menangkap jenis ikan kecil (teri) yang merupakan bahan baku usaha pengolahan ikan rebus kering (sobong) yang menjadi andalan wilayah ini. Alat tangkap jaring/pancing digunakan nelayan jaring/ pancing untuk menangkap ikan-ikan berukuran kecil dan sedang (kembung, tongkol, tenggiri, belida, udang, cumi dan lain-lain). Jika dilihat dari status para nelayan dalam usaha penangkapan ikan dapat dibedakan antara nelayan pemodal (juragan), nelayan yang memiliki alat tangkap sendiri (nelayan pemilik bagan, sebagian nelayan jaring/ pancing) nelayan yang tidak memiliki alat tangkap (nelayan buruh jaring/pancing, anak bagan). Hubungan patronase terjadi hampir di semua bagian dalam jaringan ekonomi nelayan di Pesisir Ujung Kulon. Nelayan yang tidak memiliki sarana/alat melaut seperti bagan, jaring, perahu dan lain-lain harus memiliki patron yang dapat memberikan sarana/alat melaut serta modal melaut sehingga yang bersangkutan dapat menjalankan aktivitas nafkah sehari-hari. Di sisi lain nelayan-nelayan yang sudah memiliki alat melaut seperti bagan tancap, bagan perahu dan bagan apung juga seringkali menghadapi krisis dalam penyediaan permodalan yang harus disediakan dalam setiap aktivitas mencari nafkah. Bahkan pengusaha sobong (pengolahan ikan teri rebus kering untuk ekspor) sekalipun juga harus memiliki patron yang dapat menjamin keberlangsungan usaha dan keberlangsungan aliran permodalan usaha.

Ditinjau dari prinsip hubungan ekonomi, pranata ekonomi patronase dalam sistem ekonomi nelayan pesisir Ujung $\mathrm{Ku}-$ lon memiliki bentuk hubungan yang berbeda-beda antara lain: (a) Patronase antara nelayan pemilik bagan dengan nelayan buruh bagan (anak bagan), (b) Patronase antara juragan kapal penarik bagan dengan nelayan pemilik bagan dan nelayan buruh bagan, kunca, palime-lime dan sampan, (c) patronase antara tengkulak besar, pengusaha sobong dan palele (d) patronase antara langgan dengan nelayan jaring/pancing.

\section{Patronase antara Nelayan Pemilik Bagan dan Nelayan Buruh Bagan (Anak Bagan)}

Hubungan dalam pranata ekonomi patronase terjalin antara nelayan pemilik bagan dengan anak bagan. Pemilik bagan sebagai patron memiliki sumber daya jauh lebih besar dari anak bagan karena memiliki modal dan sarana penangkapan ikan seperti bagan, jaring dan alat-alat lainnya. Anak bagan sebagai klien memiliki tenaga, keterampilan dan loyalitas yang dapat dicurahkan untuk mengoperasionalkan sumber daya yang dimiliki patron menjadi produktif. Terdapat dua macam hubungan anta- 


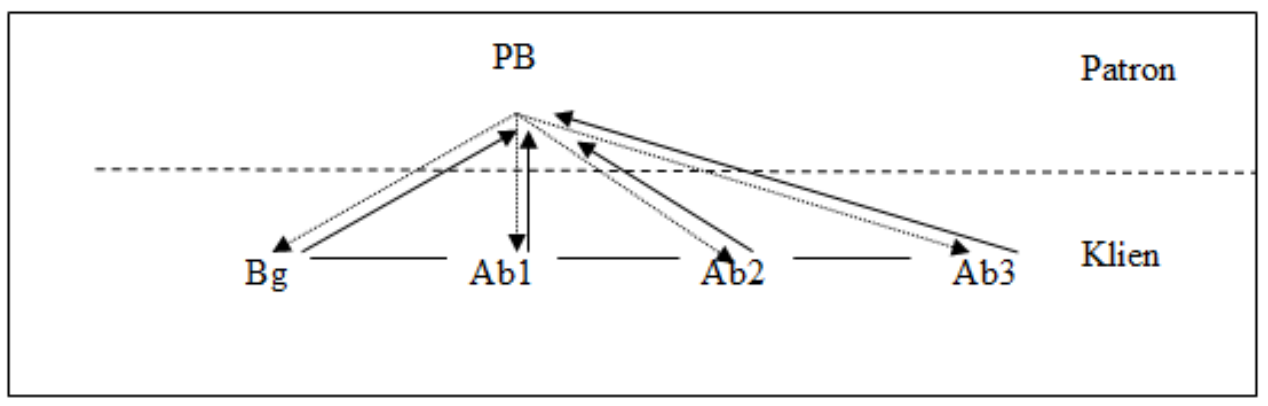

Keterangan Pelaku:

PB : Pemilik bagan perahu

Bg : Bandega = nelayan yang dipercaya oleh pemilik bagan sebagai pemimpin operasional aktivitas pemeliharaan bagan maupun penangkapan ikan

Ab : Anak Bagan = nelayan yang menjadi anak buah tetap dari bandega dan terlibat secara tetap dalam setiap aktivitas kerja bagan

Keterangan Hubungan ekonomi Patronase Pemilik bagan, Bandega dan Anak Bagan

$\rightarrow$ Mempekerjakan dan memberikan modal operasional, sarana/alat melaut

Memberikan tenaga, keterampilan dan loyalitas

Hubungan Kerjasama

$\mathrm{PB}$ = sebagai penyedia modal operasional, sarana/alat melaut

$\mathrm{Bg}, \mathrm{Ab} 1, \mathrm{Ab} 2, \mathrm{Ab}_{3}$ = sebagai penyedia Tenaga Kerja.

Gambar 1. Pranata dan Hubungan Ekonomi Patronase Nelayan Pemilik bagan, Bandega dan Nelayan Anak Bagan

ra pemilik bagan sebagai patron dan anak buahnya sebagai klien, yaitu (1) Pemilik bagan sebagai patron terjun langsung dalam aktivitas melaut, sehingga aktivitas ekonomi anak bagan langsung di bawah kontrol pemilik bagan, (2) Pemilik bagan sebagai patron tidak secara langsung terlibat dalam aktivitas melaut karena tidak memiliki waktu atau keterampilan yang cukup, sehingga aktivitas ekonomi bandega dan anak bagan tidak di bawah kontrol langsung pemilik bagan. Biasanya dalam situasi ini segala aktivitas ekonomi di bagan dipercayakan sepenuhnya kepada bandega. Bandega adalah nelayan buruh bagan yang dipercaya oleh pemilik bagan sebagai pemimpin operasional termasuk untuk melakukan kontrol terhadap aktivitas anak bagan.

Kemampuan ekonomi dari pemilik $b a-$ gan sebagai patron juga berbeda-beda. Bagi pemilik bagan yang memiliki kemampuan ekonomi yang kuat maka sebagai patron, maka dia mampu memberikan pinjaman untuk kliennya di masa krisis. Pada musim paceklik (musim paila) atau musim tangkapan sedikit, secara otomatis pendapatan bandega dan anak bagan sedikit bahkan terkadang tidak ada aktivitas mencari nafkah sama sekali. Pada situasi itulah pemilik $b a-$ gan menjadi tempat meminjam dana untuk memenuhi kebutuhan hidup bandega dan anak bagan. Kemampuan patron memberikan pinjaman pada klien akan menuntut loyalitas dan kontrol yang tinggi terhadap klien. Pinjaman yang diberikan oleh patron kepada klien akan diperhitungkan secara teliti dengan catatan-catatan pinjaman yang jelas dan terbuka. Selama pinjaman tersebut masih belum dilunasi, maka klien tidak diberi kebebasan untuk berpatron dengan pihak pemilik bagan yang lain dan pada saat aktivitas melaut berlangsung pembagian hasil akan dikontrol dengan ketat oleh patron. Dalam hal ini pinjaman merupakan semacam ikatan dari hubungan patronase yang ada. Berbeda dengan patronase di 


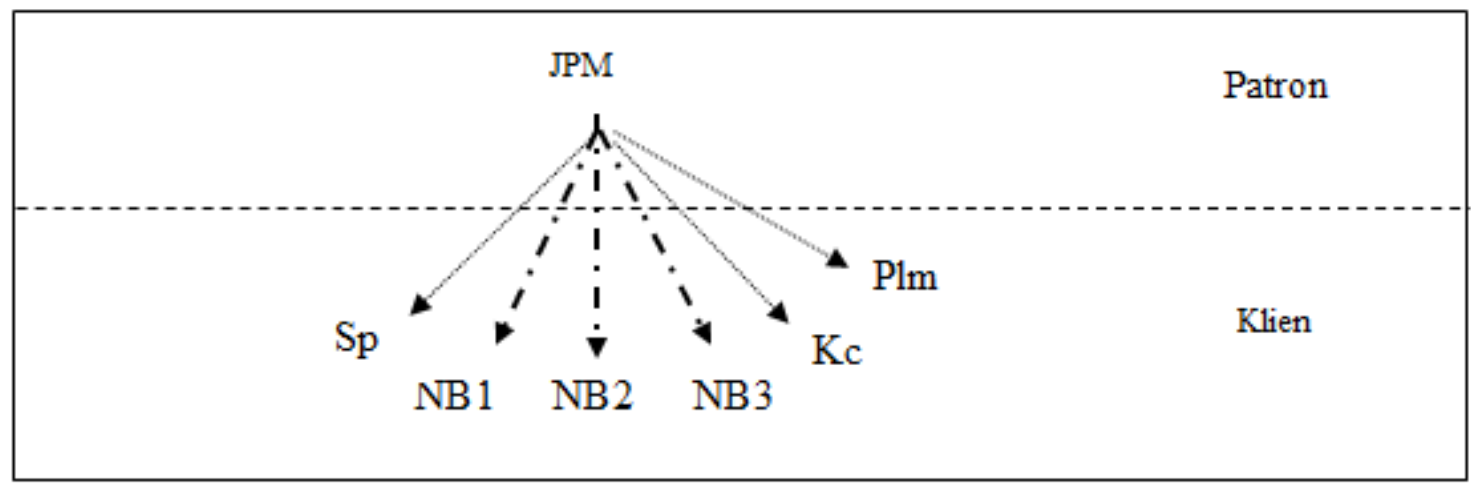

Keterangan Pelaku :

PPM : Juragan Perahu Muatan ( Kapal Motor Penarik)

Sp : Juru mudi sampan

Kc : Kunca (Juru mudi Kapal Penarik)

Plm : Palime-lime ( Tukang Kuras)

NB : Nelayan Bagan

Keterangan relasi :

$\longrightarrow=$ Dipekerjakan

$-\cdot \cdot \overrightarrow{-}=$ Rekan kerja, namun jika Pemilik Perahu Muatan berkontribusi dalam modal membuat bagan dan permodalan melaut, maka hubungannya akan berubah menjadi hubungan Patronase

Gambar 2. Pranata dan Hubungan Ekonomi Patronase pada Sistem Penangkapan Ikan Menggunakan Bagan

masa lalu dimana tata hubungan moralitas yang dijadikan dasar dalam ikatan patronase.

Arus manfaat secara materi patronase di dalam jaringan ekonomi nelayan $b a-$ gan lebih banyak mengalir kepada patron, namun klien juga menerima jaminan pekerjaan tetap, penyediaan modal, sarana dan jasa pemasaran. Jika pemilik bagan memiliki kemampuan ekonomi, maka klien juga menerima jaminan krisis subsisten berupa pinjaman yang diberikan pada saat klien menghadapi kesulitan ekonomi, walau jaminan tersebut tidak mengcover seluruh kebutuhan rumah tangga klien. Manfaat atau keuntungan yang diberikan dari klien kepada patron adalah keuntungan secara material hasil produksi, kesetiaan dan loyalitas klien menyediakan tenaga dan keahliannya untuk kepentingan patron. Sebaliknya pemilik bagan yang tidak memiliki kemampuan ekonomi, maka hubungan yang terjadi lebih didasarkan pada hubungan di mana pemilik bagan membekerjakan anak buah- nya (anak bagan) pada setiap aktivitas melaut. Jaminan yang diberikan adalah klien tetap melakukan aktivitas mata pencaharian walaupun tidak memiliki sarana/modal melaut. Namun pemilik bagan sebagai patron tidak bisa menjamin sepenuhnya sistem penghidupan klien, karena pada musim paceklik, pemilik bagan menghadapi krisis yang sama dengan para kliennya. Kelanggengan ikatan kerja vertikal antara pemilik bagan dan kliennya dibuat dengan upaya yang berbeda selain penjaminan penghidupan subsisten klien pada situasi krisis, antara lain (1) patron tidak terlalu ketat mengontrol dalam hal pembagian hasil pada saat musim tangkapan, (2) memberikan kesempatan dan kontrol yang lebih longgar terhadap kliennya ketika klien ingin membuka jaringan ekonomi baru dengan pelaku ekonomi lainnya jika hal tersebut dapat menopang sistem penghidupan mereka pada situasi krisis.

Patronase antara Juragan Kapal Penarik

UNNES JOURNAIS




\section{Bagan dengan Pemilik Bagan/Anak Bagan, Kunca, Palele dan Sampan}

Hubungan patronase lainnya yang ditemukan dalam sistem ekonomi nelayan Ujung Kulon adalah patronase antara juragan kapal penarik bagan dengan para nelayan pemilik bagan, anak bagan, kunca, palele dan sampan. Dalam sistem penangkapan ikan menggunakan bagan apung dan bagan perahu harus ditarik oleh kapal penarik yang cukup besar untuk untuk berpindah dari satu tempat ke tempat lain mengejar ground fishing, sementara nelayan pemilik bagan umumnya tidak memiliki kapal motor sendiri. Artinya nelayan bagan tidak dapat mengoperasikan bagan miliknya jika tidak ada kapal motor penarik bagan yang umumnya dimiliki oleh para juragan yang memiliki modal besar. Juragan (pemodal) yang menginvestasikan modal cukup besar (150-200 juta) dalam penyediaan sarana kapal motor penarik bagan harus memiliki langganan nelayan pemilik bagan tetap untuk menjamin biaya operasional kapal tertutupi. Juragan yang memiliki kapal motor penarik ini disebut juragan perahu muatan atau juragan kapal penarik bagan.

Mayoritas juragan kapal penarik $b a-$ gan ini merupakan pemodal yang berasal dari luar wilayah. Orientasi mereka adalah mengumpulkan pemilik bagan sebanyakbanyaknya untuk menjadi anggota tarikan mereka yang pada akhirnya berkedudukan sebagai klien dan juragan sebagai patron. Semakin banyak juragan menguasai atau memiliki anggota, maka semakin besar sumber pendapatan dan keuntungan untuk para juragan. Juragan akan berusaha mempertahankan angota dengan cara mengikat anggotanya agar tidak berpindah kepada juragan kapal motor yang lain antara lain (1) juragan menyediakan pinjaman modal melaut bagan bilamana pemilik bagan tidak memiliki dana untuk modal melaut. Seandainya aktivitas melaut tidak membuahkan hasil, maka juragan memperkenankan pemilik bagan untuk nendo (tendoan, menunda pembayaran). Pemilik bagan tidak boleh berpindah kepada juragan yang lain jika masih memiliki hutang kepada juragan tersebut, (2) juragan memberikan modal kepada anak bagan yang ingin memiliki bagan perahu sendiri dengan pembayaran dicicil. Selama masih ada hutang modal kepada juragan tersebut, selama itu pula dia harus tetap menjadi anggota tarikan dari juragan yang bersangkutan, (3) juragan memberikan uang pengikat sebesar 2-3 juta rupiah ketika bergabung menjadi anggota. Jika suatu saat pemilik bagan tersebut ingin berpindah juragan, maka ia harus mengembalikan uang pengikat tersebut.

Ketika juragan, pemilik bagan dan anak bagan berada pada ikatan hubungan patronase, maka juragan dan klien harus memenuhi hak dan kewajiban. Juragan kapal penarik dituntut memberikan jaminan permodalan yang didasarkan pada perhitungan atas pinjaman secara detil dan tertulis. Pinjaman tersebut harus dikembalikan ketika ada tangkapan ikan. Jika tidak ada hasil tangkapan maaka pinjaman tersebut terus diakumulasi.

Dasar dari terbentuknya ikatan di antara keduanya adalah prinsip saling membutuhkan, namun karena adanya perbedaan sumber daya di antara keduanya sehingga surplus ekonomi lebih banyak mengalir kepada patron. Walaupun demikian, bukan berarti klien tidak memiliki bargaining power sama sekali. Klien memiliki pertimbangan-pertimbangan ekonomi tertentu. Jika klien berpikir bahwa ikatan patron-klien yang ada cenderung merugikan dirinya maka dia akan mencari berbagai cara untuk melepaskan diri dari ikatan patronase tersebut. Kenyataannya sistem ekonomi setempat dan pasar menyediakan alternatif-alternatif cara untuk dapat keluar atau melepaskan diri dari ikatan tertentu walaupun harus masuk pada ikatan patronase yang lain dengan bentuk ikatan yang hampir sama.

Bapak Iw (42 th), seorang pemilik bagan perahu yang selama 7 tahun berpatron dengan juragan kapal penarik H Sm (57 th). Selama berpatron Bpk Iw seringkali meminjam modal melaut kepada juragan tersebut, terutama pada saat tangkapan ikan sedikit atau musim paceklik. Pada tahun 2012, pinjaman tersebut terakumulasi sebesar 15 juta rupiah. Walaupun 
pada saat tangkapan banyak Bpk Iw selalu mengembalikan pinjaman, tapi pada saat musim paila, akumulasi pinjaman tersebut terus meningkat. Akhir tahun 2012 Bpk Iw merasa hubungannya dengan juragan sudah tidak harmonis lagi, karena ketika di situasi krisis, beberapa kali pinjaman Bpk Iw ditolak oleh sang juragan. Dengan berjalannya waktu Bpk Iw merasa hubungannya dengan juragan cenderung merugikan dirinya. Sang juragan semakin sulit mengeluarkan dana pinjaman ketika masa paceklik dan musim tangkapan sedikit, sementara hasil tangkapan ikan terus menerus dipotong menjadi keuntungan juragan. Bpk Iw mengistilahkan hubungan patronasenya dengan ungkapan “ Musim tangkap ikan saya punya juragan, kalau musim paila saya tidak punya juragan” artinya sang juragan tidak mampu memberikan jaminan ekonomi pada saat krisis. Dari sini Bpk Iw memikirkan cara agar bisa terbebas dari ikatan Juragan tersebut. Namun selama masih ada ikatan pinjaman, maka dirinya tidak bisa berpindah kepada juragan yang lain. Akhirnya Bpk Iw menjual motornya seharga 10 juta rupiah dan menghubungi juragan lain yang setuju memberikan "uang pengikat" sebesar 5 juta rupiah. Terkumpullah uang sebesar 15 juta rupiah untuk melunasi semua pinjamannya kepada juragan yang pertama, kemudian secara resmi Bpk Iw berpindah patron kepada juragan yang kedua dengan uang pengikat sebesar 5 juta rupiah.

Juragan kapal motor penarik bagan selain memiliki hubungan patronase dengan pemilik bagan, juga memiliki hubungan patronase dengan kunca, palime-lime dan sampan. Kunca adalah nakhoda kapal motor penarik. Palime-lime adalah awak kapal dan tukang kuras kapal motor. Sampan adalah juru mudi sampan yang bertugas menjemput dan mengantarkan nelayan bagan ke tempat bagan atau ke kapal motor penarik yang di tambatkan di tengah laut atau ditambatkan di sekitar pulau-pulau kecil di pesisir Ujung Kulon. Relasi di antara mereka cenderung bersifat vertikal, namun umumnya mereka juga terikat pada hubungan kekerabatan (anggota kerabat) yang dibawa dari wilayah asal sang juragan, se- hingga ikatan patronase di antara mereka lebih bersifat anggota kerabat yang dipekerjakan dan mendapatkan bagian hasil dari setiap aktivitas melaut.

\section{Patronase antara Tengkulak Besar, Pen- gusaha Sobong, Palele, Tukang Rebus}

Bentuk patronase yang ketiga adalah hubungan patronase yang terjalin antara tengkulak besar, pengusaha sobong dan $p a-$ lele. Tengkulak besar adalah pedagang ikan besar (eksportir ikan) yang berkedudukan di Jakarta. Pengusaha sobong adalah pengusaha lokal yang memiliki usaha sobong yang merupakan usaha pengolahan ikan teri rebus kering untuk komoditas ekspor. Palele adalah anak buah pengusaha yang melakukan pembelian ikan teri di tengah laut. Di antara pengusaha sobong terjalin kerjasama secara vertikal yang ditentukan jaringan usaha dan jaringan ekonomi yang dimiliki. Semakin kuat jaringan ekonomi yang dimiliki oleh sobong tertentu, maka semakin besar kemungkinan untuk membuat jaringan ekonomi vertikal dengan pengusaha sobong yang lain. Pengusaha sobong yang sudah dianggap kuat umumnya permodalannya dipasok tengkulak besar yang berkedudukan sebagai patron dan pengusaha sobong sebagai klien. Tengkulak sebagai patron memasok sejumlah dana sebagai modal usaha kepada pengusaha sobong klien. Semua produksi harus dijual kepada tengkulak tersebut dengan standar harga yang telah ditetapkan sebelumnya. Kesepakatan ini berimplikasi pada terciptanya jaringan kerja baru dalam usaha sobong. Keharusan untuk menjaga kualitas teri olahan memaksa pengusaha sobong harus melakukan pembelian teri langsung pada bagan-bagan nelayan di tengah laut. Dari sini muncul pelaku ekonomi palele yang bertugas melakukan transaksi pembelian ikan di tengah laut, sehingga dengan cara ini teri yang baru ditangkap nelayan bagan dapat langsung direbus oleh tukang rebus di perahu motor yang dibawa oleh palele. Hal ini merupakan salah satu cara usaha sobong untuk menjaga kualitas teri yang dikehendaki. Palele merupakan klien dari pengusaha sobong. Palele melakukan pembelian ikan di tengah laut atas 


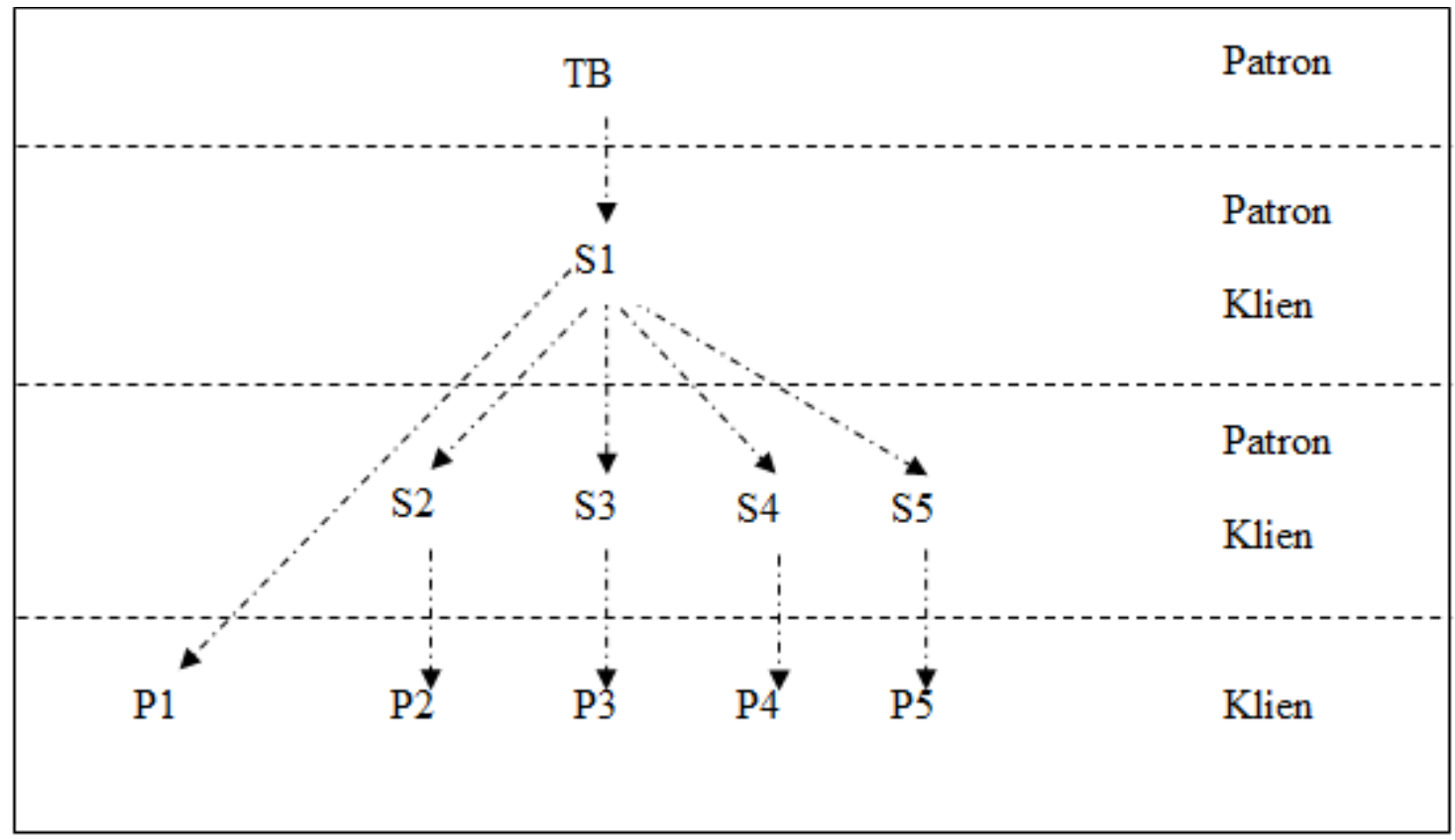

Keterangan Pelaku :

TB : Tengkulak Besar /eksportir teri kering, berkedudukan di Jakarta

S1 $\quad$ : Pengusaha sobong yang dipercaya mendapatkan kucuran modal dari TB

$\mathrm{S}_{2}-\mathrm{S}_{5}$ : Pengusaha sobong anak buah pengusaha sobong pertama $\left(\mathrm{S}_{1}\right)$

$\mathrm{P}_{1}-\mathrm{P}_{5}$ : Palele yang melakukan pembelian ikan teri di tengah laut

Keterangan relasi :

....... Memberi Modal

Gambar 3. Pranata dan Hubungan Ekonomi Patronase pada Sistem Ekonomi Sobong

modal dari pengusaha sobong, dan mendapat komisi dari jumlah pembelian teri di tengah laut, yang dihitung setiap malam bulan purnama. Pada musim paceklik, patron tetap membantu para kliennya, namun bantuan tersebut tetap diperhitungkan secara ekonomis, detil dan tertulis, bantuan ini pula yang menjadi pengikat dari hubungan patronase yang ada.

Pengusaha sobong juga dapat menjadi patron bagi pengusaha sobong lainnya. Modal yang relatif besar yang diberikan oleh tengkulak disalurkan kepada pengusahapengusaha lainnya, dengan kesepakatan pengusaha sobong besar mendapatkan fee dari setiap kilogram produk teri olahan yang dihasilkan. Pengusaha sobong besar sebagai patron juga menjamin kepastian pemasaran produk teri karena kedudukannya sekaligus menjadi pengumpul dan pemasok kepada eksporti/tengkulak ikan besar. Patron juga memberikan pinjaman modal kepada para kliennya ketika sobong tidak bisa beroperasi di musim paceklik, namun pinjaman yang diberikan kepada pengusaha sobong juga berfungsi sebagai pengikat dari hubungan patronase yang berlangsung.

\section{Patronase antara Langgan dengan Ne- layan Jaring/Pancing.}

Patronase yang terjalin antara langgan dengan nelayan jaring/pancing terkait dengan permasalahan bagaimana memenuhi aspek permodalan. Hubungan tersebut juga merupakan relasi ekonomi vertikal berupa ikatan ekonomi dengan mekanisme pertukaran antara patron dan klien. Langgan merupakan pedagang pengumpul tingkat desa yang mengumpulkan hasil tangkapan nelayan untuk dipasarkan ke wilayah atas 
desa. Sebagai patron adalah para langgan yang memberikan bantuan modal, bahan bakar, serta alat tangkap kepada klien (nelayan jaring/pancing). Patron menyediakan juga berbagai bentuk bantuan yang diperlukan klien di luar kepentingan modal melaut misalnya kebutuhan alat tangkap. Adapun pelunasan utang klien pada patron dibayarkan pada setiap penjualan hasil tangkapan. Sebagai imbalan pertukarannya, nelayan harus menjual hasil tangkapannya kepada patron dengan harga yang umumnya ditetapkan. Selisih dari harga patron dibandingkan harga pasar dianggap sebagai imbalan dari pinjaman modal dan alat tangkap yang di berikan kepada nelayan. Jika hasil tangkapan lebih sedikit daripada modal yang diberikan maka sisa pinjaman dihitung tendo (tunggakan) yang tetap harus dibayarkan nelayan ketika nelayan mendapatkan tangkapan. Secara umum nelayan jaring dan nelayan pancing menganggap keberadaan langgan sebagai patron merupakan salah satu alternatif cara dan strategi ekonomi untuk menjamin aspek permodalan mereka sehingga nelayan tetap dapat melakukan aktivitas melaut disaat tidak memiliki modal dan sarana alat tangkap sekalipun. Di sisi lain, pasokan ikan bagi langgan sebagai pedagang pengumpul ikan dapat terus berlanjut. Dari sisi patron, pinjaman yang diberikan sebenarnya tidak mengandung resiko, oleh karena jika pinjaman tersebut tidak dikembalikan dengan alasan kurangnya tangkapan ikan, maka pinjaman tersebut menjadi tunggakan (tendoan) yang tetap harus dibayarkan oleh nelayan di lain waktu. Artinya resiko kerugian tetap harus ditanggung oleh nelayan. Jika pinjaman nelayan terus terakumulasi, berarti ikatan ekonomi vertikal antara langgan dan nelayan akan tetap berlangsung dan nelayan klien tidak boleh menjual hasil tangkapannya kepada patron yang lain. Dalam hal ini patron berkedudukan sebagai price taker, namun dengan kedudukan seperti tidak berarti patron dapat semena-mena menetapkan harga, oleh karena jika klien merasa merasa terlalu dirugikan dalam konteks harga, maka klien akan mencari jalan untuk memutuskan hubungan dengan langgan tersebut. Jika terjadi pemutusan hubungan ekonomi, otomatis langgan kehilangan salah satu sumber pasokan ikan.

Sistem langgan yang terbentuk di wilayah ini menunjukan saling ketergantungan antara nelayan dan langgan. Dengan situasi seperti itu, masing-masing pihak bersedia mengambil resiko dan konsekuensi. Bagi seorang langgan yang harus selalu memberikan pinjaman kepada nelayan, maka tentu saja yang bersangkutan harus menyediakan modal dalam jumlah besar. Resikonya dapat saja modal tersebut tidak berputar dan terakumulasi berupa pinjaman-pinjaman nelayan tanpa bunga, sementara terkadang bagi patron lokal, modal tersebut merupakan modal pinjaman dari pemodal atas desa. Kerugian akan lebih besar pada saat hasil tangkapan nelayan sedikit karena jumlah pinjaman relatif sama. Keuntungannya adalah patron memiliki sumber pasokan ikan secara tetap yang mendukung kegiatan ekonominya terus berjalan. Sementara bagi nelayan, konsekuensi menjual ikan dengan harga lebih rendah harus diterima meskipun mereka berpeluang memperoleh untung yang lebih pada saat hasil tangkapannya banyak. Keuntungannya adalah nelayan jaring dan nelayan pancing tetap dapat menjalankan aktivitas ekonominya walaupun pada situasi ketiadaan modal dan sarana melaut.

Seorang nelayan jaring, Bpk An (35 th) merupakan klien dari langgan Bpk I ( 37 th). Bpk An memiliki perahu congkreng dengan mesin tempel dan jaring. Langgan seringkali memberikan bantuan modal ketika Bpk An membutuhkannya Pada musim tangkapan sedikit dan musim paila tahun lalu memiliki tendoan (tunggakan pinjaman modal) kepada langgan sebesar 5,5 juta rupiah. Selama masih ada tendoan, Bpk An terus menjual hasil tangkapannya pada langgan Bpk I. Ketika tiba musim tangkapan banyak, Bpk An, mulai mencicil sampai tendoannya terbayar semua. Begitu tunggakan pinjaman sudah terbayar, Bpk An bisa menjual hasil tangkapannya kepada siapa saja yang dianggap dapat memberikan keuntungan lebih.

Bpk Ad (42) seorang nelayan pancing yang tidak memiliki sarana melaut (pe- 


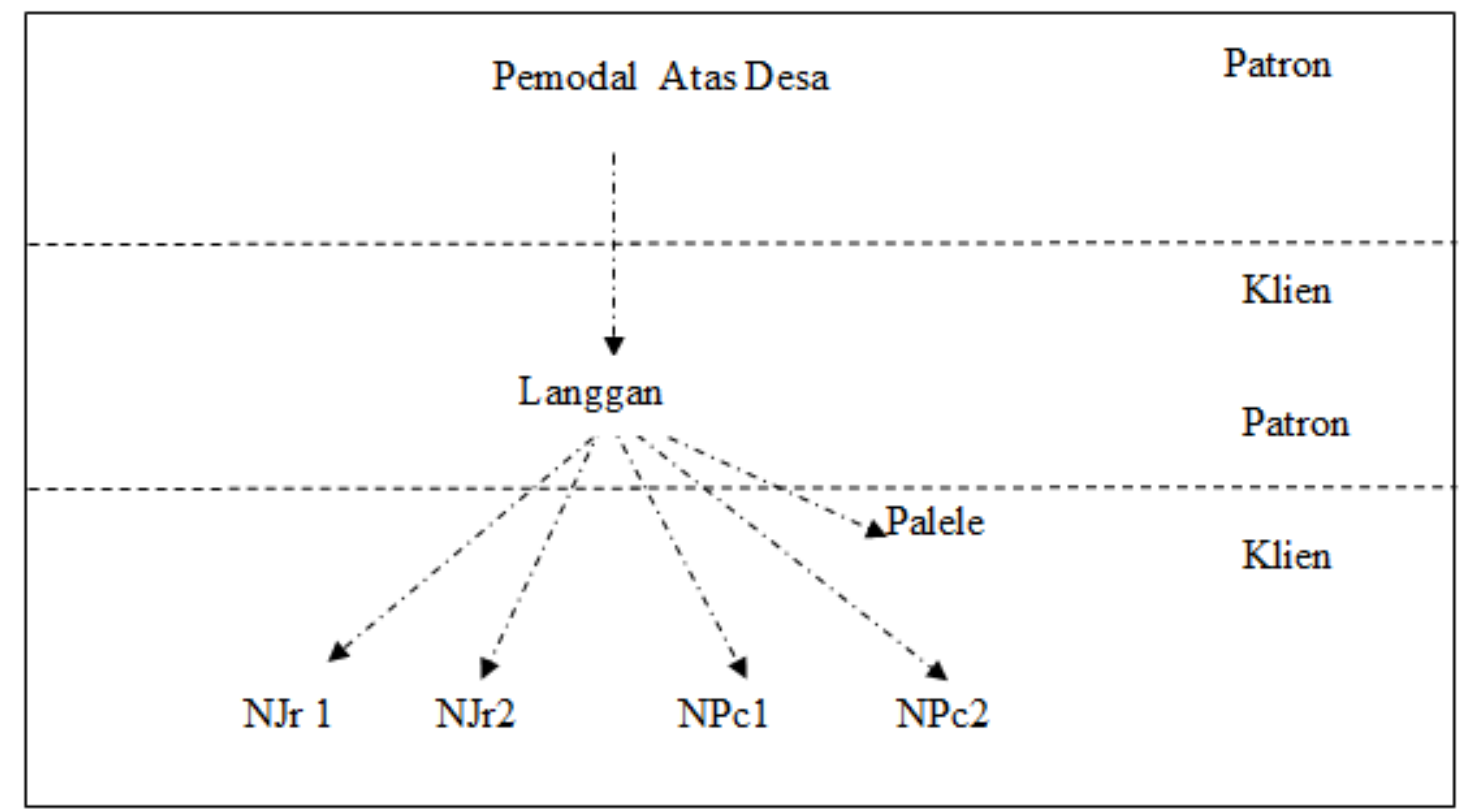

Keterangan Pelaku :

TB Labuan : Tengkulak ikan, berkedudukan di Labuan

TB Muara A : Tangkulak ikan, berkedudukan di Muara Angke

NJr 1-2 : Nelayan Jaring

NPc1-2 : Nelayan Pancing

Palele : anak buah langgan yang melakukan pembelian ikan di tengah laut

Keterangan relasi :

Memberi Modal

Gambar 4. Pranata dan Hubungan Ekonomi Patronase Langgan-Nelayan Jaring/pancing

rahu motor). Sudah empat tahun Bpk Ad menjadi klien dari langgan Bpk I (37). Langgan I memberikan bantuan permodalan ditambah menyediakan sarana melaut kepad Bpk Ad (42). Bapak Ad berusaha memelihara hubungan baik dengan langgan dengan sikap tidak pernah menjual hasil tangkapannya kepada langgan yang lain. Adakalanya di musim tangkapan banyak, tendoan sudah terbayar semua, walaupun demikian Bpk Ad tetap menjual hasil tangkapannya kepada Bpk I dengan harga pasar. Sejauh ini Bpk Ad mengaku kerjasama ekonominya dengan Bpk I tidak merugikan dirinya, walaupun dari segi keuntungan lebih banyak didapat oleh Langgan. Bpk Ad menyebut, dengan menjadi anak buah langgan Bpk I, dia tetap bisa melaut walau tidak memiliki perahu motor. Akan tetapi Bpk Ad menambahkan pula jika suatu hari kerja sama yang terjalin berubah sangat meru- gikan dirinya maka dia akan berpindah mencari langgan lain yang dapat lebih memberikan keuntungan kepada dirinya.

\section{Norma Pasar pada Patronase Masa Kini dan Keterkaitan dengan Keterjaminan Ekonomi}

Pasar adalah salah satu faktor yang memberikan kontribusi pada transformasi sosial ekonomi masyarakat. Pasar memungkinkan adanya transaksi antara pembeli dan penjual, di mana letak kekuatan pasar adalah pada aspek permintaan dan penawaran atas barang, jasa dan informasi. Pasar memfasilitasi distribusi dan alokasi serta berperan dalam pembentukan harga atas sumber daya yang ada. Dari sisi ekonomi politik, di negara kita yang cenderung mengadopsi politik ekonomi liberal, pasar menjadi motor utama penggerak perekonomian. Da- 


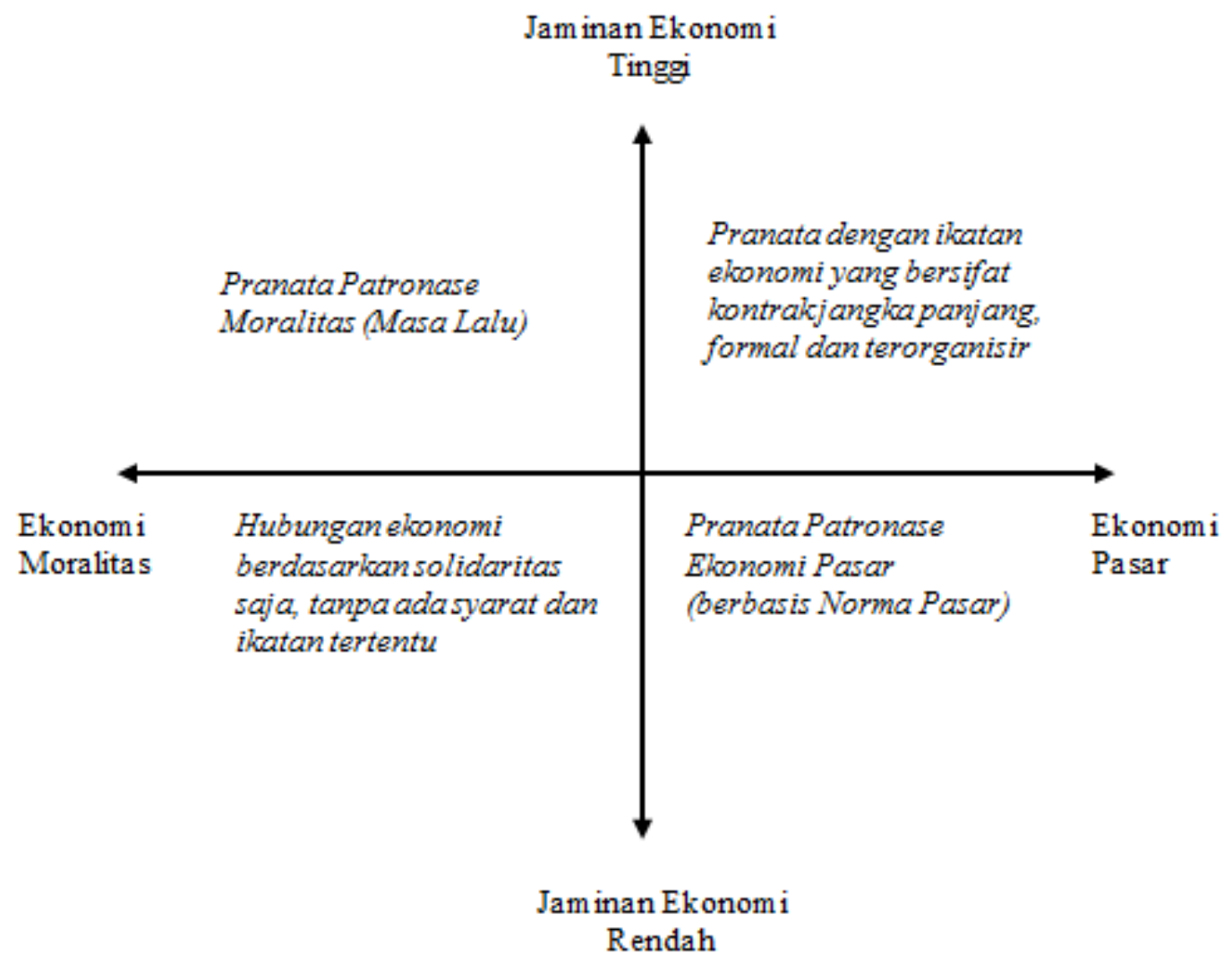

Gambar 5. Keterkaitan antara Bentuk Pranata dan Hubungan Patronase dengan Jaminan Ekonomi Nelayan

lam pandangan ekonomi liberal, di pasar, semua pelaku ekonomi baik produsen, konsumen dan distributor bekerja, berinteraksi, bertransaksi, berkompetisi dan berpartisipasi didorong oleh kepentingan pribadinya masing-masing (self interest). Selain motif kepentingan pribadi, setiap orang dalam struktur pasar akan mengeksploitasi dorongan-dorongan alamiah untuk mencari yang terbaik bagi dirinya masing-masing. Implikasinya, pelaku ekonomi diberi kebebasan memilih kombinasi dari berbagai keputusan ekonomi yang memberikan kepuasan sebesar-besarnya (utility maximization). Pelaku ekonomi juga diberi kebebasan memilih berbagai input dan teknologi yang digunakan dalam proses produksi barang dan jasa.

Ikan adalah komoditas pasar yang penting, sehingga kehadiran pasar tentu sesuatu yang dibutuhkan dan harus ada/nyata dalam masyarakat nelayan. Sistem dan nor- ma pasar mempengaruhi berbagai tindakan dan hubungan ekonomi yang terbentuk dalam masyarakat nelayan di Pesisir Ujung Kulon. Pranata ekonomi penangkapan dan pemasaran sepenuhnya terkait dengan pasar. Sehingga, hubungan, transaksi dan relasi ekonomi yang terbentuk tak lepas dari mekanisme pasar. Tentu saja mekanisme pasar juga turut mewarnai bentuk hubungan patronase yang menjadi ciri khas relasi dan pranata ekonomi nelayan setempat. Pengaruh norma pasar tampak nyata ketika dilihat dari transformasi pranata patronase di era pra ekonomi pasar dan di era ekonomi pasar di Pesisir Ujung Kulon menampilkan situasi yang tidak jauh berbeda seperti yang dikemukakan Scott (1972) yang diintisarikan pada Tabel 1.

Norma pasar secara nyata telah mentransformasi bentuk hubungan, relasi dan transaksi yang berlangsung dalam pranata patronase. Kondisi ini berlangsung karena 
Tabel 1. Transformasi Pranata Patronase dari Pra Ekonomi Pasar dan Ekonomi Pasar

\begin{tabular}{|c|c|c|c|}
\hline No & Faktor Penciri & $\begin{array}{c}\text { Patronase Pra Ekonomi } \\
\text { Pasar }\end{array}$ & $\begin{array}{c}\text { Patronase Ekonomi } \\
\text { Pasar }\end{array}$ \\
\hline 1 & $\begin{array}{l}\text { Orientasi aktivitas } \\
\text { ekonomi }\end{array}$ & $\begin{array}{l}\text { Pemenuhan Kebutuhan } \\
\text { Subsistensi }\end{array}$ & $\begin{array}{l}\text { Pemenuhan Kebutuhan di } \\
\text { atas subsistensi }\end{array}$ \\
\hline 2 & $\begin{array}{l}\text { Dasar pengambilan } \\
\text { keputusan ekonomi }\end{array}$ & $\begin{array}{l}\text { Harmoni atas hubungan/ } \\
\text { relasi ekonomi yang terbina }\end{array}$ & $\begin{array}{l}\text { Mengambil pilihan terbaik } \\
\text { dari alternatif pilihan yang } \\
\text { tersedia }\end{array}$ \\
\hline 3 & $\begin{array}{l}\text { Relasi dan transaksi } \\
\text { ekonomi }\end{array}$ & $\begin{array}{l}\text { Tidak semata perhitungan } \\
\text { ekonomi }\end{array}$ & $\begin{array}{l}\text { Didasari perhitungan eko- } \\
\text { nomi }\end{array}$ \\
\hline 4 & Interaksi ekonomi & $\begin{array}{l}\text { Saling membutuhkan dan } \\
\text { saling menolong }\end{array}$ & $\begin{array}{l}\text { Saling membutuhkan dan } \\
\text { saling mementingkan diri } \\
\text { sendiri }\end{array}$ \\
\hline 5 & $\begin{array}{l}\text { Asas/ basis hubun- } \\
\text { gan ekonomi }\end{array}$ & Moralitas & Rasionalitas Pasar \\
\hline 6 & $\begin{array}{l}\text { Kelanggengan ika- } \\
\text { tan }\end{array}$ & Relatif langgeng & $\begin{array}{l}\text { Tergantung kepentingan } \\
\text { ekonomi }\end{array}$ \\
\hline 7 & $\begin{array}{l}\text { Sumber daya yang } \\
\text { dipertukarkan }\end{array}$ & Material dan immaterial & material \\
\hline 8 & $\begin{array}{l}\text { Perbedaan sumber } \\
\text { daya yang dimiliki } \\
\text { patron-klien }\end{array}$ & Besar dan jelas & $\begin{array}{l}\text { Relatif sedikit dan kurang } \\
\text { jelas }\end{array}$ \\
\hline 9 & $\begin{array}{l}\text { Kontrol patron ter- } \\
\text { hadap klien }\end{array}$ & Kuat & Kurang kuat \\
\hline 10 & Loyalitas Klien & Loyal & Kurang loyal \\
\hline 11 & $\begin{array}{l}\text { Jaminan yang dicov- } \\
\text { er Patron }\end{array}$ & Luas/jaminan subsistensi & $\begin{array}{l}\text { Terbatas (dengan perhitun- } \\
\text { gan ekonomi) }\end{array}$ \\
\hline 12 & Resiko & $\begin{array}{l}\text { Menghindari resiko atau re- } \\
\text { siko didistribusikan tanpa } \\
\text { perhitungan ekonomi }\end{array}$ & $\begin{array}{l}\text { Mengambil resiko atau re- } \\
\text { siko didistribusikan dengan } \\
\text { perhitungan ekonomi }\end{array}$ \\
\hline 13 & Surplus & $\begin{array}{l}\text { Diakumulasi untuk masa } \\
\text { krisis }\end{array}$ & $\begin{array}{l}\text { Untuk saving, investasi } \\
\text { dan konsumsi } \\
\text { Mengandalkan surplus sav- } \\
\text { ing }\end{array}$ \\
\hline 14 & Asuransi & $\begin{array}{l}\text { Mengandalkan patronase } \\
\text { sebagai institusi asuransi }\end{array}$ & $\begin{array}{l}\text { Mengandalkan relasi eko- } \\
\text { nomi alternatif di luar pa- } \\
\text { tronase }\end{array}$ \\
\hline & & & $\begin{array}{l}\text { Memberdayakan seluruh } \\
\text { anggota keluarga untuk } \\
\text { mencari nafkah (straddling } \\
\text { strategy) }\end{array}$ \\
\hline 15 & $\begin{array}{l}\text { Posisi Klien atas pili- } \\
\text { han ekonomi }\end{array}$ & Tidak memiliki pilihan lain & Memiliki pilihan alternatif \\
\hline 16 & Peranan modal & Tidak terlalu Vital & Sangat Vital \\
\hline 17 & Persaingan & $\begin{array}{l}\text { Dianggap mengganggu ke- } \\
\text { selarasan hubungan eko- } \\
\text { nomi }\end{array}$ & $\begin{array}{l}\text { Menyediakan alternatif dan } \\
\text { peluang ekonomi baru }\end{array}$ \\
\hline
\end{tabular}

Ket : Faktor Penciri Diadaptasikan dari Scott (1972) 
seluruh pelaku pasar yang terdiri dari nelayan, juragan (pengusaha perikanan), pedagang dan lain-lain tidak dapat menghindar dari tekanan norma pasar. Jika ditinjau dari keterjaminan ekonomi, pranata patronase di masa lalu lebih memberikan jaminan keamanan ekonomi kepada klien di situasi krisis, karena patron meng"cover" jaminan atas penghidupan klien relatif lebih luas daripada patronase masa kini. Segala faktor penciri yang terdapat dalam hubungan patronase berbasis moralitas ini memberikan implikasi bahwa patronase moralitas, memberikan jaminan ekonomi yang tinggi kepada nelayan.

Pranata patronase ekonomi pasar (berbasis Norma Pasar) memberikan jaminan ekonomi yang relatif lebih rendah. Hal ini disebabkan adanya fakta bahwa :

Transaksi ekonomi yang berlangsung antara patron dan klien yang didasari perhitungan ekonomi cenderung mengurangi "solidaritas vertikal" di antara kedua-nya. Relasi yang terbangun lebih didasarkan pada hubungan kontrak yang telah ditetapkan, bukan resiprositas yang seperti umumnya digambarkan pada patronase masa lalu. Transaksi input produksi dan pembagian hasil tangkapan sudah diatur secara jelas, detil dengan pencatatan, sehingga kalaupun ada "bantuan" lain dari patron terhadap klien akan dianggap sebagai "hutang" yang harus dibayarkan oleh klien.

Hubungan patronase terbentuk atas asas saling membutuhkan, namun keduanya juga saling mementingkan diri sendiri (self interest) yang mengurangi "solidaritas vertikal dan trust".

Ikatan ekonomi yang terbentuk cenderung tergantung kepentingan ekonomi, sehingga sifatnya kurang langgeng. Ikatan ekonomi setiap saat bisa saja putus karena kepentingan ekonomi yang berubah, sehingga ikatan ekonomi yang ada tidak memberikan jaminan ekonomi.

Pada situasi di mana pranata patronase tidak bisa sepenuhnya berfungsi sebagai institusi jaminan ekonomi nelayan, yang dilakukan nelayan untuk tetap "survive" pada situasi ekonomi yang kurang terjamin antara lain mengandalkan surplus saving, mengandalkan relasi ekonomi alternatif di luar patronase serta memberdayakan seluruh anggota keluarga untuk mencari nafkah (straddling strategy).

Jaminan ekonomi akan tinggi jika pranata ekonomi pasar yang ada memiliki ikatan ekonomi yang bersifat kontrak jangka panjang, formal dan terorganisir.

\section{SIMPULAN}

Masyarakat nelayan di Pesisir Ujung Kulon mengalami transformasi sosial ekonomi akibat penetrasi pembangunan dan pasar dengan ideologi kapitalisme dan modernisme. Transformasi sosial ekonomi yang terjadi membawa perubahan signifikan dalam hal pranata ekonomi, di mana terjadi transformasi patronase dari berbasis moralitas menjadi berbasis norma ekonomi pasar. Pada pranata patronase berbasis moralitas, segala aktivitas ekonomi pertukaran dan transaksi ekonomi serta dasar pengambilan keputusan seluruh pelaku-pelaku ekonomi sepenuhnya didasarkan nilai-nilai moralitas ekonomi, sementara patronase berbasis ekonomi pasar didasarkan pada norma-norma ekonomi pasar. Kondisi ini berlangsung karena seluruh pelaku ekonomi perikanan yang terdiri dari nelayan, juragan (pengusaha perikanan), pedagang dan lain-lain tidak dapat menghindar dari tekanan norma ekonomi pasar. Pranata patronase tetap merupakan suatu alternatif pranata ekonomi nelayan yang dibangun untuk tetap bertahan dengan situasi krisis dan ketidakpastian serta mata pencaharian yang bersifat fluktuatif. Dengan kata lain pranata ekonomi patronase merupakan salah satu pranata ekonomi penopang sosial ekonomi nelayan, walaupun pasar menyediakan pilihan-pilihan ekonomi yang lain.

Ditinjau dari keterjaminan ekonomi, pranata patronase moralitas di masa lalu lebih memberikan jaminan keamanan ekonomi nelayan pada situasi krisis, karena patron memberikan jaminan atas penghidupan klien relatif lebih luas. Sebaliknya, pranata patronase berbasis norma ekonomi pasar kurang memberikan jaminan ekonomi pada masa krisis kepada nelayan. Pada situasi di mana pranata patronase tidak bisa 
sepenuhnya berfungsi sebagai institusi jaminan ekonomi nelayan, yang dilakukan nelayan untuk tetap bertahan pada situasi ekonomi yang kurang terjamin antara lain mengandalkan relasi ekonomi alternatif yang disediakan pasar di luar patronase.

\section{UCAPAN TERIMAKASIH}

Artikel ini merupakan bagian dari Penelitian Disertasi Mahasiswa Program Doktor Sekolah Pascasarjana Program Studi Sosiologi Pedesaan IPB. Ucapan terimakasih disampaikan kepada Ekawati S. Wahyuni selaku Dosen Sekolah Pascasarjana IPB. Ketua Komisi Pembimbing, Arif Satria selaku Dosen Sekolah Pascasarjana IPB. Anggota Komisi Pembimbing, Saharuddin selaku Dosen Sekolah Pascasarjana IPB. Anggota Komisi Pembimbing, Tridoyo Kusumastanto selaku Guru Besar Bidang Ilmu Kebijakan Ekonomi Perikanan dan Ilmu Kelautan Fakultas Perikanan dan Ilmu Kelautan. Anggota Komisi Pembimbing

\section{DAFTAR PUSTAKA}

Allison, E.H. 2009. Vulnerability of National Economies to The Impact of Climate Change on Fisheries. Fish and Fisheries Journal Compilation. Blackwell Publishing Ltd

Baran, E. N. Schwartz. 2009. Climate Change and Fisheries; Vulnerability and Adaptation in Cambodia. The Worldfish Center. Penang. Malaysia. www.worldfishcenter.org

Basurto, X. 2013. Cooperative \& Non Cooperative Strategies For Small Scale Fisheries, Self Governance in The Globalization Era : Implica- tions For Conservation. Ecology $\mathcal{E}$ Society $18(4): 38$.

Dharmawan, A.H. 2001. Farm Household Livelihood Strategies and Socio-economic Changes in Rural Indonesia. Wissenschaftsverlag Vauk Kiel $K G$. Germany

De la T-C., M. Lars, L. 2010. Fishing Institution ; Addressing Regulative, Normative and Cultural Cognitive Elements to Enhance Fisheries Management. Marine Policy. 34 (1): 77-84

Deliarnov. 2006. Ekonomi Politik. Penerbit Erlangga. Jakarta

Granovetter, M. 2001. The Strength of Weakness. American Journal Sociology. 78: 1360-1380

Khan, Niaz Ahmed. 2001. Social Forestry Versus Social Reality : Patronage \& Community Based Forestry in Bangladesh. International Institute for Environment and Development.

Lenggono, PS. 2011. Ponggawa dan Patronase Pertambakan di Delta Mahakam: Teori Pembentukan Ekonomi Lokal. Disertasi SPD-IPB

Lyon, Stephen M. 2002. Power and Patronage in Pakistan. University of Kent. Canterbury

Popkin, Samuel L. 1986. Petani Rasional. Lembaga Penerbit Yayasan Padamu Negeri. Jakarta

Scott, James C. 1972. The Erosion of Patron Cleint Bonds and Social Change in Rural Southeast Asia. Journal Asian Studies. 32 (1)

Scott, James C. 1989. Moral Ekonomi Petani. LP3ES. Jakarta

Satria, Arif. 2009. Pesisir dan Laut untuk Rakyat. IPB Press. Bogor

Satria, Arif. 2002. Pengantar Sosiologi Masyarakat Pesisir. PT. Pustaka Cidesindo. Jakarta

Verelst, Bram. 2013. Managing inequality: The Political Ecology of A Small-Scale Fishery. Journal of Political Ecology. 20: 14-36

Weber, Max. 1958. The Protestan Ethic and The Spirit Capitalism, translated by Talcott Parson. Charles Scribners. New York 